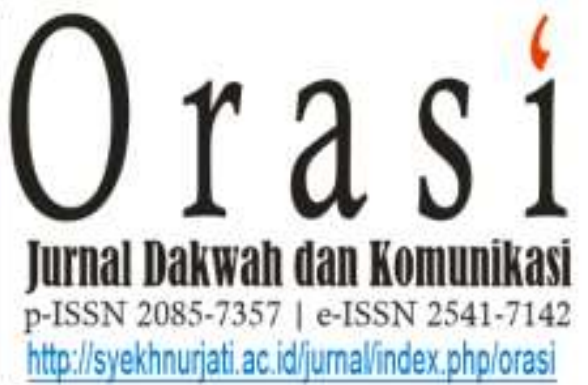

Volume 11 No. 2 Desember 2020

\title{
PENGARUH INTENSITAS MENGGUNAKAN TIK TOK TERHADAP PERILAKU BODY SHAMING ANAK
}

\section{THE EFFECT OF THE INTENSITY IN USING TIKTOK ON CHILDREN'S BODY SHAMING BEHAVIOR}

\author{
Hanifah Islamiyah ${ }^{1, a)}$ \\ ${ }^{1}$ Program Studi Magister Ilmu Komunikasi, Universitas Diponegoro Semarang

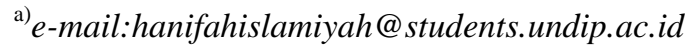

\begin{abstract}
ABSTRAK
Kepopuleran Tik Tok telah merekonstruksi standar kecantikan baru. Hal tersebut dibarengi dengan anak sebagai pengguna Tik Tok yang mulai memperhatikan tubuh orang lain dan membandingkan dengan dirinya sendiri. Dengan media sosial, anak mendapatkan pengalaman melihat gambar dan unggahan lainnya mengenai gambaran kecantikan yang ideal. Fenomena yang kemudian muncul adalah tindakan body shaming. Tujuan Penelitian ini adalah untuk mengetahui hubungan dan besaran pengaruh intensitas Tik Tok terhadap perilaku body shaming anak. Teori yang digunakan adalah Teori S-R. Intensitas menggunakan TikTok merupakan stimulus atau rangsangan, dan perilaku body shaming sebagai respon. Metode yang digunakan adalah penelitian eksplanatif dengan pendekatan kuantitatif dan desain penelitian yang digunakan adalah survey. Populasi penelitiannya adalah anak SD yang ada di Kota Cirebon. Teknik samplingnya adalah multistage cluster sampling, dan siswa kelas 6B SD Negeri Kebon Baru 5 sebagai sample. Uji validitas menggunakan Pearson Product Moment dan uji reliabilitas menggunakan Alfa Cronbach, kemudian data diuji normalitas, uji liniearitas, dan uji korelasi menggunakan Korelasi Pearson dan uji regresi. Hasil penelitian adalah intensitas anak menggunakan Tik Tok memberikan besaran pengaruh sebesar $34 \%$ terhadap perilaku body shaming anak. Hal ini diperkuat dengan Teori S-R bahwa stimulus dari penggunaan media Tik Tok menghasilkan respon yang sesuai dengan konstruk pesan media tersebut. Saran penelitian selanjutnya dapat menambah faktor-faktor lain yang berhubungan dengan perilaku body shaming.
\end{abstract}


Kata Kunci: Body Shaming, Perilaku Anak, Tik Tok

\begin{abstract}
TikTok's popularity has reconstructed new beauty standards. It leads children as TikTok users to start paying attention to other people's bodies and compare them with theirs. With social media, children get the experience of seeing images and other uploads on the ideal beauty picture. The phenomenon that then arises is the body-shaming behavior. The purpose of this research was to find out the relation and effect of the intensity in using TikTok on children's body shaming behavior. The theory applied was the S-R Theory. The intensity of using TikTok was a stimulus and body shaming behavior is the response. The method used was an explanative research method with the quantitative approach. The research design applied was a survey. The research population was children in Cirebon City. The sampling technique was multistage cluster sampling with the students in grade $6 B$ of SD Negeri Kebon Baru 5 as the samples. The validity test used was Pearson Product Moment and the reliability testing used was Alfa Cronbach. The data were tested for normality, linearity test, and correlation test using Pearson Correlation and regression test. The results show that the intensity of children using TikTok gave a magnitude of 34\% effect on children's body shaming behavior. This had been strengthened by the S-R theory that the stimulus from the usage of TikTok produced a response that was in accordance with the constructed messages of the app. The suggestion for further research is to add other factors related to body shaming behavior.
\end{abstract}

Keywords: Body Shaming, Children's Behaviour, TikTok

\section{Pendahuluan}

Semenjak tersedianya jaringan komunikasi data nirkabel terbaru 4G-LTE, yang mengungguli jaringan sebelumnya yang berskala $3 \mathrm{G}$ dan 3.5G, kemampuan masyarakat untuk mengakses internet dengan kecepatan dan kapasitas menjadi lebih unggul. Kesempatan ini juga dilihat oleh berbagai perusahaan di bidang Information and Technology (IT) untuk menciptakan aplikasiaplikasi hiburan yang membutuhkan kecepatan dan kapasitas yang besar.

Salah satunya adalah aplikasi berbagi video yang sangat populer saat ini. Aplikasi berbagi video merupakan teknologi komunikasi untuk mengirimkan video secara langsung kepada pengguna lain melalui jaringan internet. Teknologi video streaming merupakan teknologi yang mampu menyampaikan informasi dalam bentuk tampilan video secara langsung. (Damayanti dan Gemiharto 2019).

Salah satu aplikasi berbagi video yang populer di Indonesia adalah aplikasi Tik Tok. Aplikasi yang memfasilitasi penggunanya untuk merekam, memasukkan suara, gambar, stiker, filter dan editing, membagikan video yang sudah dibuat, dan ditransmisi ke media lainnya yang mendukung ini resmi masuk ke Indonesia pada tahun 2016. Berdasarkan laporan yang dimuat Tirto, aplikasi Tik Tok menduduki aplikasi nomor 1 di App Store dan di tahun 2018 Tik Tok menerima penghargaan dari Google Play sebagai “Aplikasi Paling 
Menghibur" dan "Aplikasi Terbaik". Sampai pada saat tulisan ini dibuat (26/05/2020), Tik Tok berada di urutan kedua "Aplikasi Gratis Populer" di Google Play Store dengan 100 juta+ penginstal.

Kepopuleran Tik Tok tidak hanya memberikan sarana hiburan baru bagi pengguna internet, tapi juga telah merekonstruksi standar kecantikan baru utamanya bagi Generasi Z. Dalam sebuah artikel yang dimuat dalam Vice yang ditulis oleh Raisin Lanigan (Lanigan 2019) mengungkapkan bahwa pengguna Instagram dan blog telah beralih ke Tik Tok untuk mendapatkan kiat gaya, inspirasi estetika, dan tutorial kecantikan. Jika Instagram memberikan seperangkat standar kecantikan untuk Generasi Milenial, Tik Tok melakukan hal yang sama untuk Generasi $\mathrm{Z}$ dengan cara yang lebih mendukung dan menarik. Lanigan mendeskripsikan gadis-gadis pengguna Tik Tok dengan gadis yang menggunakan rok tenis A-line, T-shirt berlapis dengan turtleneck lengan panjang, menguncir rambut, kaus kaki di atas lutut, dan beberapa riasan kreatif yang serius seperti hidung dan pipi tampak merah merona, riasan mata eyeliner cair digunakan untuk menyempurnakan model cat eye setajam silet, gambar hati atau bintang di tulang pipi yang tinggi. Lanigan menyebutnya dengan $E$ Girl.

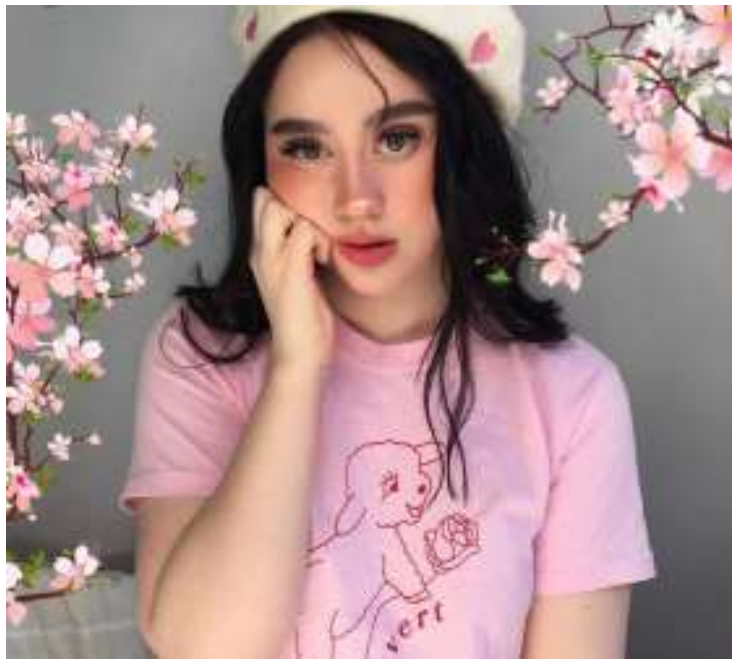

Gambar 1. Suntingan Foto Pengguna Tik Tok yang Bergaya Softgirl Sumber: yada.land https://yada.land/t/girls-and-theiraesthetic-1-soft-girl-inspo-tiktok-1h9nu37j5s

Fenomena standar kecantikan yang direkonstruksi dan diredefinisi oleh pengguna Tik Tok yang mayoritas Generasi $\mathrm{Z}$ juga diulas tajam oleh Adrienne Matei (Matei 2019) dalam The Guardian. Apabila Lanigan menyebutnya E-Girl, Matei menyebutnya softgirl. Gadis pengguna Tik Tok akan dianggap cantik apabila menggunakan jepit rambut, menggunakan warna-warna yang lembut, memakai mom's jeans, bibir mengkilap, dan secara keseluruhan bertemakan dreamy, rambut dikuncir, menggunakan pastel, riasan bintik-bintik di pipi, gambar awan atau hati di wajah, serta pipi yang dicat merona dan hidung yang memerah.

Standar kecantikan Tik Tok sangat berbeda dan tidak pernah ada sebelumnya di media lain. Hal itu disebabkan karena aplikasi Tik Tok yang mendukung proses editing dan filter yang tidak dimiliki kebanyakan media sosial lain seperti Instagram, Twitter, atau Facebook. Sedangkan aplikasi berbagai video 
atau sunting video lainnya tidak secara spesifik membentuk karakter cantik atau lucu yang khusus yang coraknya berbeda dari media lainnya.

Media sosial, sebagaimana Tik Tok juga berperan di dalamnya, secara perlahan berkembang menjadi media yang mempresentasikan anak laki-laki dan perempuan untuk mendefinisikan "kesempurnaan" dan "kecantikan" yang telah dimulai dari penghargaan diri mereka sendiri (self-esteem). Anak yang beranjak remaja, khususnya perempuan, telah mengalami masalah citra tubuh (body image) dan penerimaan penampilan yang harus diterima orang lain dengan cukup serius. Menurut Matei (Matei 2019), pada usia muda anak mulai memperhatikan tubuh orang lain dan membandingkan dengan dirinya sendiri. Mereka mulai berpikir untuk mengubah diri mereka. Dengan media sosial anak mendapatkan pengalaman melihat gambar dan unggahan lainnya mengenai gambaran kecantikan yang ideal.

Fenomena yang kemudian muncul adalah tindakan body shaming. Body shaming adalah bentuk dari tindakan mengomentari fisik, penampilan, atau citra diri seseorang (Geofani 2019). Salah satu video Tik Tok yang mengandung pandangan body shaming adalah unggahan akun Tik Tok bernama @afifahriyad. Videonya tersebut menunjukkan sebuah komentar dari seorang netizen yang mengomentari fisik adiknya, komentar tersebut berbunyi "mirip cm adeknya krg dirawat aja, kalo rambutnya dilurusin sm sering handbodyan, mirip sm kknya, sm2".
Video tersebut meraih 12 juta kali diputar dan 973.8 suka.

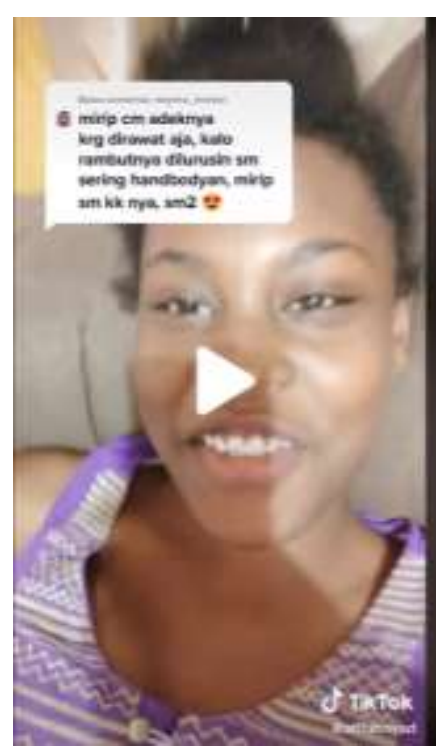

Gambar 2. Tangkapan Layar Tik Tok @ afifahriyad yang Mendapatkan Komentar Body Shaming

Sumber: https://www.tiktok.com/@afifahriyad /video/ 6846411569446931714?lang=id

Adapun ciri-ciri perilaku body shaming, adalah 1) mengkritik penampilan sendiri, melalui penilaian atau perbandingan dengan orang lain (seperti: "Saya sangat jelek dibandingkan dia." "Lihatlah betapa luas bahuku.") 2) Mengkritik penampilan orang lain di depan mereka, (seperti: "Dengan paha itu, Anda tidak akan pernah mendapatkan teman kencan.") 3) Mengkritik penampilan orang lain tanpa sepengetahuan mereka. (seperti: "Apakah Anda melihat apa yang dia kenakan hari ini? Tidak menyanjung." "Paling tidak Anda tidak terlihat seperti dia!") (Vargas 2015).

Body shaming memberikan dampak buruk yang besar bagi pelaku maupun korban tindakan tersebut. Salah satunya seperti hasil penelitian yang dilakukan (Chairani 2018) 
bahwa berdasarkan studi meta-analisis menunjukkan bahwa korelasi antara body shame dengan gangguan makan sangat kuat. Hasil penelitian tersebut menguatkan asumsi empiris dan teoritis yang mengklaim bahwa peran body shame pada kerentanan, kemunculan, dan keberlangsungan gangguan makan lebih kuat dibandingkan dengan konsep malu secara umum.

Oleh karena itu, rumusan permasalah penelitian ini adalah; (1) apakah ada hubungan yang signifikan antara intensitas menggunakan Tik Tok dengan perilaku body shaming anak?; dan (2) seberapa besar pengaruh intensitas menggunakan Tik Tok terhadap perilaku body shaming?. Tujuan Penelitian ini adalah untuk mengetahui hubungan intensitas Tik Tok terhadap perilaku body shaming anak, dan besaran pengaruh intensitas Tik Tok terhadap perilaku body shaming.

Penelitian sebelumnya (Juszczyk 2015) yang berjudul "Fields of Impact of Social Media on Youth - Methodological Implications" yang diterbitkan di Acta Technologica Dubnica Volume 5, 2015, Issue 2. Pada penelitian ini Juszczyk melihat besarnya penggunaan situs media sosial yang umum digunakan dalam aktivitas sehari-hari anak dan remaja saat ini. Dengan menghimpun penelitian-penelitian sebelumnya yang telah dilakukan oleh para ilmuwan, Juszczyk menggunakan metode field research (penelitian lapangan) dan menghasilkan beberapa kesimpulan.

Media sosial memberikan manfaat yang sebesar untuk menunjang kegiatan sehari-hari anak. Anak dapat belajar mengelola waktu dengan efektif, mengembangkan kemampuan seni dan memaknai pesan kontekstual, dan berkomunikasi mengenai informasi yang jelas dengan khalayak. Media sosial juga membantu anak-anak yang memiliki keterbatasan untuk berkomunikasi secara langsung dengan teman mampu berkomunikasi dengan baik melalui internet, membantu anak yang berkebutuhan khusus tetap terhubungan dengan teman-temannya, dan anak-anak yang sakit yang harus tinggal di rumah untuk tetap terkoneksi dengan temanteman sekolahnya untuk berbagi tugas pelajaran.

Namun, media sosial memudahkan orang asing yang tidak bertanggung jawab mendapatkan akses informasi pribadi anak, seperti alamat tinggal, nomor telefon, bahkan menghampiri rumah anak secara langsung. Sampai saat ini isu akses informasi pribadi anak dari ketidakamanan masih belum mendapatkan solusi yang akurat.

Dampak buruk lainnya seperti perilaku pelecehan dan persekusi yang dilakukan di media sosial. Rendahnya regulasi diri (selfregulation) yang masih dimiliki anak memungkinkan timbulnya tekanan antar teman sebaya (peer pressure), cyber-bullying, cyberstalking, percakapan yang mengandung cyberharrasment, eksperimen seksual, membeberkan serangan pribadi di publik, serta aksi agresi verbal lainnya yang terjadi di media sosial. Pelanggaran norma lainnya yang terjadi pada anak melalui media sosial adalah perilaku rasisme, seksisme, dan homophobia.

Hasil penelitian ini menunjukkan bahwa media sosial berpengaruh besar 
terhadap perilaku anak. Oleh karena itu, penelitian ini membuktikan bahwa terdapat hubungan antara media sosial terhadap perilaku anak.

Penelitian terdahulu yang serupa dengan penelitian ini pernah dilakukan oleh Devi Aprilian, Yessy Elita, dan Vira Afriyati yang berjudul Hubungan Antara Penggunaan Aplikasi TikTok dengan Perilaku Narsisme pada Siwa Sekolah Menengah diterbitkan di Jurnal Ilmiah BK Consilia Universitas Bengkulu Volume 2 Nomor 3 2019. Penelitian yang dilakuan Aprilian, Elita, dan Afriyati (2019) ini melihat perkembangan teknologi dengan jaringan internet dan media sosial. Perkembangan ini juga sejalan dengan perilaku narsisme anak remaja untuk menunjukkan eksistensi dan keunggulan diri sendiri. Media sosial akhirnya menjadi ruang untuk mengekspresikan diri. Penelitian ini bertujuan untuk mengetahui hubungan penggunaan Tik Tok dengan perilaku narsisme. Penelitian ini menghasilkan analisis data bahwa tingkat penggunaan aplikasi Tik Tok siswa memiliki hubungan positif signifikan terhadap perilaku narsisme. Nilai signifikansi menunjukkan bahwa semakin tinggi penggunaan aplikasi Tik Tok, maka akan semakin tinggi perilaku narsis siswa.

Penelitian yang telah dilakukan oleh (Juszczyk 2015) dan (Aprilian, Elita, dan Afriyati 2019) berbeda dengan penelitian yang sedang dilakukan ini, kedua penelitian ini tidak menggunakan teori S-R sebagai konsep berpikir untuk menguji hipotesis penelitian. Persamaan kedua artikel ilmiah di atas adalah pengaruh konsumsi media sosial terhadap variabel terpengaruh perilaku khalayak anak dan anak remaja saja. Pada penelitian yang telah dibuat (Aprilian, Elita, and Afriyati 2019) hanya berfokus pada menguji hubungan penggunaan aplikasi Tik Tok terhadap perilaku anak, sedangkan penelitian ini juga akan mengetahui besaran pengaruh yang diberikan penggunaan Tik Tok terhadap perilaku tersebut. Simpulan dari hasil dua penelitian di atas adalah bahwa terdapat hubungan antara intensitas menggunakan media terhadap variabel berpengaruh afeksi.

Teori Stimulus-Respon atau disingkat Teori S-R adalah teori yang menaruh perhatian pada proses individu menjembatani antara sederetan respon dan beraneka ragam stimulasi internal maupun eksternal yang dijumpainya (Morissan 2013). Dalam asumsi perumus teori, Ivan Pavlov, mengibaratkan dengan pembunyian secara bersamaan antara stimulus tak terkondisi sebagai daging atau makanan yang lezat dan stimulus terkondisi sebagai bunyi sendok dan garpu yang beradu di atas piring, lama kelamaan tanpa adanya daging (stimulus tak terkondisi), dengan bunyi sendok-garpu di atas piring (stimulus terkondisi) dapat membangkitkan air liur atau rasa lapar (respon) (Morissan 2013).

Asumsi teori ini secara sederhana adalah menggambarkan proses komunikasi sederhana yang melibatkan dua komponen yaitu media massa dan khalayak. Derasnya arus komunikasi di media massa membuat paparan informasi negatif semakin mudah mengenai khalayak. Pesan negatif sebagai stimulus yang terdapat di media sosial seseorang yang kemudian dibaca oleh 
penggunanya memberikan respon berupa reaksi emosional atau perilaku negatif lainnya yang diakibatkan oleh stimulus negatif, proses ini disebut membentuk label negatif (negative judgement) (Geofani 2019).

Pada penelitian ini, skema teori yang diterapkan dengan variabel-variabel yang digunakan dalam penelitian ini akan membentuk skema berikut:

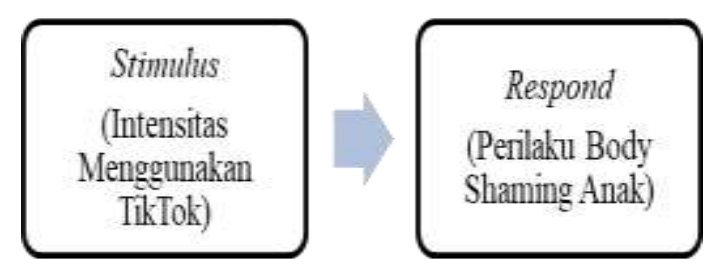

Gambar 3. Variabel Penelitian dalam Skema Teori S-R Sumber: diolah oleh peneliti

Intensitas menggunakan TikTok merupakan stimulus atau rangsangan yang datang dari luar diri seorang khalayak, dan respon atau tanggapan ialah akibat yang timbul dari adanya rangsangan yang muncul dari dalam diri responden. Berdasarkan penelitian sebelumnya, telah terbukti bahwa terdapat pengaruh yang positif antara intensitas menggunakan media sosial semacam Tik Tok terhadap perilaku khalayak.

Adapun hipotesis dari penelitian ini adalah sebagai berikut:

a. $\mathrm{H}_{1}=$ Terdapat hubungan positif antara intensitas menggunakan Tik Tok dengan perilaku body shaming anak.

b. $\mathrm{H}_{2}=$ Terdapat pengaruh positif antara intensitas menggunakan Tik Tok terhadap perilaku body shaming anak.

\section{Metodologi Penelitian}

Penelitian ini menggunakan metode penelitian dengan tipe penelitian eksplanatif dengan pendekatan kuantitatif. Desain penelitian ini menggunakan desain penelitian survey. Survey adalah prosedur peneliti mengelola data dengan mengambil sejumlah sampel dari seluruh populasi untuk menggambarkan sikap, pendapat, perilaku, atau nilai tertentu untuk menjustifikasi seluruhnya. Survey menggunakan alat kuesioner dalam menghimpun data mengenai intensitas konsumsi media, pengetahuan dan sikap masyarakat (Kriyantono 2006).

Populasi penelitian ini adalah anakanak yang ada di Kota Cirebon. Usia anakanak menurut Departemen Kesehatan Republik Indonesia tahun 2009 berada pada usia 5 sampai 11 tahun, dan remaja awal usia 12 sampai 16 tahun. Untuk mendapatkan sampel anak-anak yang menggunakan aplikasi Tik Tok, penelitian ini mengambil jarak usia antara kedua kelompok usia tersebut. Teknik samplingnya adalah multistage cluster sampling, yakni teknik penarikan sampling gugus merupakan teknik penarikan sample yang dapat digunakan apabila peneliti tidak memiliki kerangka sampling (sampling frame). Hal tersebut bisa disebabkan ukuran populasi yang sangat besar, letak geografis yang sangat luas, dan jumlah populasinya tidak diketahui. Model teknik sampling ini menghendaki peneliti mengurutkan unsur-unsur secara berjenjang secara formal untuk mengambil sampel dalam gugus tertentu di dalam wilayah populasi (Bajari 2015). Misalnya dari Provinsi 
- Kabupaten - Kecamatan - Kelurahan - RW $-\mathrm{RT}$.

Penelitian ini menggunakan sample dalam dua tahap atau lebih. Teknik yang diterapkan adalah sample gugus banyak tahap minimal dua tahap (multistage cluster sampling). Subsample dalam penelitian ini adalah; populasi keseluruhan dari penelitian ini adalah seluruh sekolah dasar yang ada di seluruh Kota Cirebon yang berjumlah 159 sekolah dasar negeri dan swasta. Dari jumlah tersebut diacak dan mendapatkan sub-sampel pertama yakni SD Negeri Kebon Baru 5 Kota Cirebon. Populasi kedua adalah seluruh kelas di SD Negeri Kebon Baru 5 Kota Cirebon yang memiliki 14 kelas dari tingkat kelas 1 sampai kelas 6, dari 14 kelas tersebut diacak kembali dan mendapatkan kelas 6 B sebagai sample penelitian ini yang berjumlah 11 siswa. Selain sampel penelitian, penelitian ini juga menggunakan 11 anak lainnya di luar sampel penelitian untuk melakukan try out uji validitas dan reliabilitas.

Teknik pengumpulan data yang digunakan dalam penelitian ini adalah angket daring Google Form yang dibagikan dalam grup Whatsapp kelas. Angket penggunaan aplikasi Tik Tok dan perilaku body shaming dikembangkan sendiri oleh peneliti dengan menggunakan model skala likert. skala likert merupakan skala yang digunakan untuk mengukur sikap, pendapat, dan persepsi seseorang atau kelompok orang tentang kejadian atau gejala sosial (Sugiyono 2010, 132). Tipe yang digunakan dalam instrumen penelitian adalah likert, variabel yang akan diukur dijabarkan menjadi indikator variabel, kemudian indikator tersebut dijadikan sebagai titik tolak untuk menyusun item-item pernyataan atau pertanyaan. Responden akan mengisi kuesioner dengan jawaban dalam bentuk ordinal 4 pilihan jawaban yang kemudian diintervalisasikan dengan memberikan skor pada setiap pilihan jawaban. Skala akan dikelompokkan menjadi 4 kategori yakni: sangat rendah atau tidak pernah dengan skor (1), rendah atau jarang dengan skor (2), tinggi atau sering dengan skor (3), dan sangat tinggi atau sangat sering dengan skor (4).

Sebelum angket diberikan pada sampel, angket diberikan pada 11 orang di luar sampel untuk menguji validitas item pertanyaan dan reliabilitas sehingga tetap dan dapat dilakukan pada penelitian selanjutnya. Uji validitas intrumen penelitian menggunakan Pearson Product Moment dan uji reliabilitas instrumen penelitian menggunakan Alfa Cronbach. Hasil uji validitas menunjukkan bahwa dengan jumlah sampel 11 responden $(\mathrm{N}=11)$ dan taraf signifikansi $5 \%$ bernilai $\mathrm{r}$ tabel 0,602, semua item pertanyaan memiliki nilai $r$ hitung di atas $r$ tabel, yang berarti seluruh item pertanyaan valid untuk diajukan pada sampel penelitian. Hasil uji reliabilitas menunjukkan nilai $\mathrm{r}_{11}$ ialah 0.08 , yang berarti nilai relibilitas berada di atas 0.06. Nilai instrument dapat dikatakan reliabilitas apabila jika nilai $\mathrm{r}_{11}$ lebih besar dari 0.06 . Yang berarti $\mathrm{r}_{11} 0.08>0.06$ instrumen pertanyaan memiliki nilai reliabilitas yang tinggi dan dapat digunakan kembali pada penelitian selanjutnya. Intrumen penelitian dapat dinyatakan dapat digunakan dalam penelitian. 
Setelah angket diisi oleh sampel penelitian, data yang diperoleh dianalisis menggunakan uji normalitas, uji liniearitas, dan uji korelasi menggunakan Korelasi Pearson dan uji regresi. Hasil uji penelitian tersebut juga akan dihitung untuk menemukan tingkat signifikan untuk mendapatkan hasil akhir penelitian yang juga signifikan.

\section{Hasil dan Pembahasan}

Instrumen yang valid dan reliabel telah mendapatkan hasil data yang diperoleh dari sampel penelitian. Hasil jawaban responden dibuat distribusi jawaban. Distribusi jawaban tersebut menghasilkan kategorisasi nilai dari setiap variabel penelitian. Variabel $\mathrm{X}$ dalam distribusi jawaban responden adalah intensitas menggunakan aplikasi Tik Tok dan variabel Y adalah Perilaku body shaming anak.

Tabel 1. Distribusi Jawaban Responden Penelitian Mengenai Variabel Intensitas Menggunakan Tik Tok

\begin{tabular}{|c|c|c|c|}
\hline \multirow[b]{2}{*}{ No Responden } & \multicolumn{3}{|c|}{ Intensitas Menggunakan Tik Tok } \\
\hline & $\begin{array}{c}\text { Berapa kali kamu } \\
\text { membuka aplikasi Tik Tok } \\
\text { dalam satu hari? }\end{array}$ & \begin{tabular}{|c|} 
Berapa lama kamu \\
menonton video-video \\
Tik Tok dalam satu hari?
\end{tabular} & $\begin{array}{l}\text { Berapa kali kamu pernah } \\
\text { membuat video Tik Tok? }\end{array}$ \\
\hline 1 & 2 & 2 & 4 \\
\hline 2 & 2 & 1 & 1 \\
\hline 3 & 1 & 1 & 1 \\
\hline 4 & 4 & 2 & 2 \\
\hline 5 & 1 & 3 & 1 \\
\hline 6 & 4 & 2 & 4 \\
\hline 7 & 4 & 2 & 4 \\
\hline 8 & 1 & 1 & 2 \\
\hline 9 & 4 & 2 & 2 \\
\hline 10 & 1 & 1 & 1 \\
\hline 11 & 4 & 3 & 2 \\
\hline
\end{tabular}

Sumber : Hasil Olah Peneliti

Berdasarkan data distribusi jawaban responden mengenai intensitas menggunakan Tik Tok, peneliti dapat membuat kategorisasi intensitas responden penelitian. Untuk membuat kategori, perlu diketahui terlebih dahulu lebar interval atau jarak antara masingmasing kategori dari jumlah skor jawaban responden. Setelah menggunakan rumus I=
$\mathrm{R} / \mathrm{K}, \mathrm{I}=4,5$. Maka tabulasi dari kategori responden adalah sebagai berikut.

Tabel 1. Kategorisasi Responden dalam Intensitas Menggunakan Tik Tok

\begin{tabular}{|cc|l|r|r|}
\hline Kelas Interval & Kategori & Jumlah & Persentase \\
\hline 3 & $\mathbf{7 . 5}$ & Rendah & 5 & 45,55 \\
\hline 7.5 & 12 Tinggi & 6 & 54.55 \\
\hline & & 11 & $100 \%$ \\
\hline
\end{tabular}

Sumber: Hasil Olah Peneliti

Kategorisasi intensitas dari distribusi jawaban responden tersebut ditemukan bahwa lebih dari separuh dari responden $(54.54 \%)$ berkategori memiliki intensitas menggunakan aplikasi Tik Tok tinggi. Artinya, sebagian besar anak memiliki intensitas menggunakan aplikasi Tik Tok tinggi.

Tabel 3. Distribusi Jawaban Responden Mengenai Perilaku Body Shaming

\begin{tabular}{|c|c|c|c|}
\hline \multirow{2}{*}{ No Responden } & $\begin{array}{c}|c| \\
\text { Ppakah kamu pernah } \\
\text { membandingkan tubuh } \\
\text { kamu lebih buruk } \\
\text { dibandingkan orang lain? } \\
\text { Misalkan, kamu merasa }\end{array}$ & $\begin{array}{c}\text { Apakah kamu pernah } \\
\text { mengkritik penampilan } \\
\text { orang lain di depan } \\
\text { orangnya? Misalnya } \\
\text { "Kamu jangan pakai baju }\end{array}$ & $\begin{array}{c}\text { Apakah kamu pernah } \\
\text { mengkritik penampilan orang } \\
\text { lain di belakang orang } \\
\text { tersebut? Misalnya } \\
\text { membicarakan model rambut }\end{array}$ \\
\hline 1 & 2 & 2 & 2 \\
\hline 2 & 4 & 2 & 2 \\
\hline 3 & 2 & 2 & 2 \\
\hline 4 & 2 & 4 & 4 \\
\hline 5 & 2 & 2 & 2 \\
\hline 6 & 4 & 4 & 4 \\
\hline 7 & 4 & 4 & 4 \\
\hline 8 & 2 & 2 & 4 \\
\hline 9 & 4 & 2 & 2 \\
\hline 10 & 4 & 2 & 2 \\
\hline 11 & 4 & 2 & \\
\hline
\end{tabular}

Sumber: Hasil Olah Peneliti

Berdasarkan data distribusi jawaban responden mengenai perilaku body shaming, peneliti dapat membuat kategorisasi perilaku responden penelitian. Telah diketahui lebar interval antara masing-masing kategori setelah menggunakan rumus $\mathrm{I}=\mathrm{R} / \mathrm{K}, \mathrm{I}=4,5$. Maka tabulasi dari kategori responden adalah sebagai berikut.

Tabel 4. Kategorisasi Perilaku Body Shaming Responden

\begin{tabular}{|rr|l|r|r|}
\hline Kelas Interval & & Kategori & Jumlah & Persentase \\
\hline $\mathbf{3}$ & $\mathbf{7 . 5}$ & Rendah & 3 & 27.27 \\
\hline 7.5 & $\mathbf{1 2}$ & Tinggi & 8 & $\mathbf{7 2 . 7 3}$ \\
\hline & & & 11 & $100 \%$ \\
\hline
\end{tabular}

Sumber: Hasil Olah Peneliti 
Kategorisasi perilaku dari distribusi jawaban responden tersebut ditemukan bahwa sebagian besar responden (72.73 \%) berkategori memiliki perilaku body shaming yang tinggi.

Setelah diketahui kategorisasi anak berdasarkan masing-masing kelas variabel, peneliti melakukan tabulasi silang terhadap jawaban kedua variabel responden sehingga menemukan hasil keterkaitan antara keduanya. Dari tabulasi silang, dapat ditemukan bahwa seluruh $(100 \%)$ anak yang memiliki intensitas menggunakan Tik Tok yang rendah memiliki tingkat perilaku body shaming sedang. Ketika lebih dari separuh (66.6 \%) intensitas menggunakan Tik Tok anak sedang, tingkat perilaku body shaming meningkat menjadi tinggi. Begitupun ketika lebih dari separuh anak-anak (66.6 \%) memiliki intensitas menggunakan Tik Toknya tinggi, tingkat perilaku body shaming pun tinggi.

Tabel 5. Tabulasi Silang dari Distribusi Jawaban Responden

\begin{tabular}{|l|c|c|c|}
\hline \multirow{2}{*}{ Intensitas Menggunakan Tik Tok } & \multicolumn{2}{|c|}{ Perilaku Body Shaming Anak } & \multirow{2}{*}{ Total } \\
\cline { 2 - 3 } & Rendah & Tinggi & \\
\hline Rendah & $2(40.00)$ & $3(60.00)$ & $5(45.45)$ \\
\hline Tinggi & $1(16.67)$ & $5(83.33)$ & $6(54.55)$ \\
\hline Total & $3(27.27)$ & $8(72.73)$ & $11(100.00)$ \\
\hline
\end{tabular}

Sumber : Hasil Olah Peneliti

Antara intensitas menggunakan Tik Tok dan tingkat perilaku body shaming telah ditemukan memiliki keterkaitan. Lebih dari separuh anak (60\%) yang intensitas menggunakan Tik Toknya rendah memiliki perilaku body shaming tinggi, dan sebagian besar anak (83.33\%) memiliki intensitas menggunakan Tik Tok yang tinggi dan memiliki perilaku body shaming yang tinggi.
Namun, apakah ada hubungannya antara intensitas menggunakan Tik Tok dengan tingkat perilaku body shaming anak? Untuk mengetahuinya, perlu dilakukan uji korelasi. Dalam penelitian ini menggunakan Uji Korelasi Pearson.

Hasil uji Korelasi Pearson menunjukkan bahwa dari jawaban responden ditemukan nilai Pearsonnya adalah 0.666076936 atau 0.666. Nilai Pearson harus lebih tinggi atau besar dari nilai dari Tabel $r$ Korelasi Pearson. Untuk menentukan nilai $r$ dari Tabel Korelasi Pearson, menggunakan rumus $\mathrm{df}=(\mathrm{N}-2)$, atau df $=(11-2)$ dengan tingkat signifikansi 0.05 , diperoleh angka $r$ tabel Korelasi Pearson yakni 0.621 . Artinya $0.666>0.621$, berarti berdasarkan tabel makna nilai Korelasi Pearson, bahwa angka 0.666 menunjukkan hubungan intensitas menggunakan Tik Tok memiliki hubungan yang tinggi/kuat dengan tingkat perilaku body shaming anak. Hasil uji korelasi juga menunjukkan nilai $\mathrm{R}^{2} 0.054437$. Nilai $\mathrm{R}^{2}$ menunjukkan signifikansi kekuatan hubungan intensitas menggunakan Tik Tok dan perilaku body shaming anak. Dengan nilai $(\mathrm{df}=11-2=9)$ adalah 0.05214, maka $0.054437>0.05214$ yang berarti kekuatan hubungan intensitas menggunakan Tik Tok dengan perilaku body shaming signifikan.

Hasil uji Korelasi Pearson menunjukkan bahwa $\mathrm{H}_{1}$ bahwa terdapat hubungan positif antara intensitas menggunakan Tik Tok dengan perilaku body shaming anak. 
Tabel 6 dan 7. Hasil Statistik Uji Regresi

\begin{tabular}{l|r|}
\hline & \multicolumn{1}{c|}{ Coefficients } \\
\hline Intercept & $\mathbf{5 . 0 7 1 0 9 0 0 4 7}$ \\
X Variable 1 & $\mathbf{0 . 5 3 0 8 0 5 6 8 7}$ \\
\hline SUMMARY OUTPUT \\
\hline \multicolumn{2}{|c|}{ Regression Statistics } \\
\hline \multicolumn{2}{|c|}{$\mathbf{0 . 6 6 6 0 7 6 9 3 6}$} \\
\hline Multiple R & $\mathbf{0 . 4 4 3 6 5 8 4 8 5}$ \\
\hline R Square & 0.381842761 \\
\hline Adjusted R Square & 1.735543614 \\
\hline Standard Error & 11 \\
\hline Observations
\end{tabular}

Sumber: Hasil Olah Peneliti

Rumus untuk mengetahui besaran pengaruh intensitas menggunakan Tik Tok terhadap tingkat perilaku body shaming anak menggunakan uji regresi. Hasil uji regresi menunjukkan bahwa intensitas menggunakan Tik Tok memberikan pengaruh sebesar 0.530805687 terhadap perilaku body shaming anak.

Tabel 8. Sumbangan Efektif Intensitas Menggunakan Tik Tok terhadap Perilaku Body Shaming Anak

\begin{tabular}{|c|c|c|c|c|c|}
\hline Variabel & Regresi & Relasi & RSquare & SE & $\%$ \\
\hline Intensitas Menggunakan Tik Tok & 0.53 & 0.66 & 0.44 & 0.3498 & $34 \%$ \\
\hline
\end{tabular}

Sumber: Hasil Olah Peneliti

Dengan mendapatkan nilai regresi atau besaran pengaruh intensitas dan nilai R Square sebesar 0.443658485, maka diketahui intensitas menggunakan Tik Tok memberikan konstribusi atau sumbangan secara efektif sebesar $34 \%$ terhadap tingkat perilaku body shaming anak.

Hasil pengujian hipotesis dari uji regresi menunjukkan bahwa $\mathrm{H}_{2}$ intensitas menggunakan Tik Tok memberikan pengaruh positif terhadap perilaku body shaming anak.
Tik Tok adalah aplikasi yang saat ini banyak digunakan oleh pengguna internet. Bahkan, beberapa saluran televisi membuat program siaran yang secara khusus menayangkan video-video Tik Tok, seperti saluran televisi NET TV yang memiliki program "TikTokan" dan "Retjeh", GTV memiliki program "Warbiasak", dan saluran televisi lainnya yang memiliki program serupa. Kepopuleran Tik Tok juga telah membawa perubahan tren mengenai gaya dan estetika penggunanya. Dengan fitur-fitur ciri khasnya, Tik Tok membentuk model kecantikan baru yang disukai oleh generasi $\mathrm{Z}$ sehingga menciptakan kepopuleran fashion dan tampilan make up yang baru. Sebagaimana media sosial lainnya, pengguna (user) yang memiliki pengikut (follower) dengan jumlah yang sangat banyak, mereka akan menjadi trendsetter dan opinion leader mengenai tren dalam bidang medi sosial tersebut (Lanigan 2019).

Namun, berdasarkan data pengguna aktif aplikasi Tik Tok, anak-anak dengan kelompok usia di bawah generasi $\mathrm{Z}$, yakni anak-anak dengan kelompok usia 10-13 tahun yang termasuk dalam generasi Alpha merupakan kelompok usia kedua pengguna terbesar aplikasi Tik Tok. 39.9 persen atau jumlah kelompok usia pengguna Tik Tok berada pada rentang umur 10 sampai 19 tahun yang artinya mencakup generasi $\mathrm{Z}$ dan generasi Alpha.

Sebagai media audio dan visual, Tik Tok memberikan ruang bagi anak untuk mengekspresikan dengan bebas kreatifitas, citra diri, kegemaran, ketertarikan, dan 
minatnya dengan menciptakan video. Fasilitas yang dimiliki oleh Tik Tok seperti menyisipkan musik, rekaman suara, emoticon, stiker, gambar, filter suasana gambar yang mencolok atau kalem, dan kelebihan fitur lainnya mendukung pembuatan video yang lebih variatif.

Namun, sebagai internet citizen (netizen) muda, anak-anak pengguna Tik Tok menjadi opinion follower atau pengguna media yang mengikuti atau mencontoh opinion leader dalam bidang tertentu. Sebagai netizen Tik Tok, opinion leadernya adalah celebtiktok atau pengguna Tik Tok yang memiliki jumlah like, view, comment, dan follower banyak. Celebtiktok juga pengguna Tik Tok yang video-video buatannya menjadi trendsetter atau populer karena viral.

Untuk menciptakan video yang populer, pengguna Tik Tok harus memiliki ide yang kreatif dan berbeda agar banyak menarik perhatian pengguna yang lain. Dengan menggunakan fitur-fitur yang ada, proses pembuatan video-video Tik Tok dibuat agar menampilkan kebolehan dirinya sendiri. Menurut Aprilian, Elita, dan Afriyati (2019) sebagai perilaku narsisme.

Pengguna Tik Tok menggunakan berbagai macam cara untuk mempercantik dirinya sebagai bentuk kecintaan terhadap dirinya sendiri. Bentuk narsisme sebagai kecintaan terhadap diri sendiri diwujudkan dalam bentuk gerak dan ucapan secara berlebihan atau perhatian yang sangat besar pada penampilan seperti dijelaskan Aprilian, Elita, dan Afriyati (2019).
Menurut (Vaisman 2019, 174), menampilkan gaya dan penyesuaian dengan zaman serta mengikuti tuntutan standar kecantikan yang baru merupakan bagian dari proses perkembangan psikologis memasuki masa remaja. Nilai yang dimasukkan sebagai ideologi palsu oleh Tik Tok untuk memahami konsep cantik dan gaya yang baru menjadi pengetahuan bagi netizen yang belum mendapatkan konsep femininitas sebelumnya.

Nilai mengenai kecantikan, estetika, dan gaya yang masuk sebagai ideologi palsu tidak hanya diterapkan pada dirinya sendiri untuk tampil di muka umum, tapi juga sebagai nilai bahkan pedoman pandangannya untuk menilai kecantikan, estetika, dan gaya orang lain. Nilai mengenai kecantikan, atau apa yang dapat diterima sebagai kecantikan, kemudian digunakan untuk mengeliminasi imej-imej yang ditemui dan kemudian berubah menjadi laku. Perilaku ini kemudian disebut sebagai perilaku body shaming.

Rendahnya literasi media yang dimiliki oleh generasi $\mathrm{Z}$ dan generasi di bawahnya menunjukkan bahwa pengguna Tik Tok dari kalangan anak remaja dan anak-anak belum dapat menggunakan media sosial dengan bijak (Wahyuti 2018). Daya literasi media adalah sebuah kemampuan yang harus dimiliki khalayak untuk menyaring, memproses, mencerna, dan memilih pesan tekstual dan kontekstual dari media sosial, sehingga khalayak respon yang timbul dari stimulus tidak melalui proses kognisi yang baik.

Hasil penelitian telah menunjukkan bahwa Tik Tok memiliki hubungan yang 
signifikan dengan perilaku body shaming anak. Lebih dari separuh anak-anak memiliki intensitas yang tinggi dalam menggunakan Tik Tok, baik dari frekuensi membuka aplikasi, menonton video, maupun membuat video Tik Tok. Perilaku body shaming anak-anak berkategori tinggi menunjukkan bahwa hampir seluruh anak-anak menilai dirinya sendiri lebih jelek/buruk dari orang lain. Anak-anak juga mengatakan secara langsung pada orang lain untuk tidak mengenakan sesuatu karena dapat membuat orang tersebut lebih jelek/buruk, dan anak-anak juga membicarakan kejelekan/keburukan penampilan orang lain dengan temannya tanpa sepengatahuan orang tersebut.

Intensitas menggunakan Tik Tok secara signifikan memiliki hubungan dengan perilaku body shaming anak, bahkan intensitas menggunakan Tik Tok anak telah memberikan kontribuksi efektif sebesar $34 \%$ terhadap perilaku body shaming anak.

\section{Simpulan dan Saran}

Berdasarkan hasil survey yang telah dilakukan didapatkan bahwa intensitas menggunakan Tik Tok anak-anak berkategori tinggi dan perilaku body shaming anak berkategori tinggi. Hasil uji Korelasi Pearson menunjukkan bahwa intensitas menggunakan Tik Tok berhubungan positif secara signifikan dengan perilaku body shaming dengan taraf $0.054437>0.05214$ yang berarti kekuatan hubungan intensitas menggunakan Tik Tok dengan perilaku body shaming signifikan. Hasil uji regresi menunjukkan bahwa intensitas menggunakan Tik Tok memberikan pengaruh sebesar $34 \%$ secara signifikan terhadap perilaku body shaming anak.

Perilaku body shaming merupakan perilaku anak yang memiliki penilaian buruk terhadap diri sendiri dan membandingbandingkan penampilan diri sendiri dengan orang lain, mengatakan secara langsung kepada orang lain mengenai penampilannya yang buruk, dan juga membicarakan keburukan penampilan orang lain di belakangnya yang dipengaruhi oleh intensitas anak menggunakan Tik Tok karena Tik Tok telah membongkar definisi kecantikan dan membentuk standar kecantikan yang baru.

Dari hasil penelitian ini diharapkan orang tua selalu mengawasi anak-anak dalam penggunaan Tik Tok baik saat membuka aplikasi Tik Tok, menonton video Tik Tok, dan membuat video Tik Tok. Pengawasan orang tua juga diiringi dengan pemahaman mengenai makna kecantikan, membangun selfesteem pada anak, dan cara menilai orang lain tidak hanya dari penampilan.

Penelitian ini memiliki keterbatasan dalam proses penelitian. Teknik sampling yang hanya menghimpun sedikit sampel dan teknik pengumpulan data yang digunakan dapat dilakukan perbaikan pada penelitian selanjutnya. Dengan kondisi Pandemi Covid19 yang mengharuskan peneliti mengikuti protokol keselamatan sesuai anjuran pemerintah, penelitian selanjutnya disarankan menghimpun sampel penelitian yang lebih banyak dan teknik penyebaran angket yang lebih efektif sehingga mendapatkan respon penelitian yang lebih beragam. 
Saran untuk penelitian selanjutnya juga diharapkan dapat menambah variabel berpengaruh lain seperti pengaruh media sosial Instagram, atau menambah variabel anteseden seperti variabel intensitas menggunakan smartphone anak. Selain itu, penelitian selanjutnya dapat menambah faktor-faktor lain yang berhubungan dengan perilaku body shaming, sehingga faktor-faktor tersebut dapat diketahui sebagai penyebab tinggi dan rendahnya perilaku body shaming anak.

\section{Daftar Pustaka}

Aprilian, Devri, Yessy Elita, and Vira Afriyati. 2019. "Hubungan Antara Penggunaan Aplikasi Tiktok Dengan Perilaku Narsisme Pada Siswa Sekolah Menengah Pertama." Consilia 2 (3): 220-28.

Bajari, Atwar. 2015. Metode Penelitian Komunikasi. Bandung: Simbiosa Rekatama Media.

Chairani, Lisya. 2018. "Body Shame Dan Gangguan Makan Kajian Meta-Analisis." Buletin Psikologi 26 (1): 12-27. https://doi.org/10.22146/buletinpsikologi. 27084.

Damayanti, Trie, dan Ilham Gemiharto. 2019. "Kajian Dampak Negatif Aplikasi Berbagi Video Bagi Anak-Anak Di Bawah Umur Di Indonesia." Communication $10 \quad$ (1): 1. https://doi.org/10.36080/comm.v10i1.80.

Geofani, Dela. 2019. "Pengaruh Cyberbullying Body Shaming Pada Media Sosial Instagram Terhadap Kepercayaan Diri Wanita Karir Di Pekanbaru." Jom Fisip 6: 2-6.

Juszczyk, Stanisław. 2015. "Fields of Impact of Social Media on Youth Methodological Implications." Acta Technologica Dubnicae 5 (2): 80-86. https://doi.org/10.1515/atd-2015-0066.

Kriyantono, Rachmat. 2006. Teknik Praktis
Riset Komunikasi. Jakarta: Kencana.

Lanigan, Raisin. 2019. "How TikTok Is Changing Beauty Standards for Gen Z i-D." In Vice. https://id.vice.com/en_us/article/vb99em/tik-tokbeauty-standards-e-girl-make-up.

Matei, Adrienne. 2019. “TikTok's Soft Girls: Could a Hyper-Cute Aesthetic Be a Symbol of Empowerment." In The Guardian.

https://www.theguardian.com/lifeandstyl e/2019/dec/04/tiktok-soft-girl-femininityempowerment-culture.

Morissan. 2013. Teori Komunikasi: Individu Hingga Massa. Jakarta: Prenadana Media Group.

Sugiyono. 2010. Metode Penelitian Kuantitatif, Kualitatif, Dan $R \& D$. Bandung: Alfabeta.

Vaisman. 2019. "Menampilkan Masa Remaja Menggunakan Bahasa Digital Dalam Israblogging." In Wacana Digital. Jakarta: Kencana.

Vargas, Erika. 2015. "Body Shaming: What Is It \& Why Do We Do It? - Walden Eating Disorders."

https://www.waldeneatingdisorders.com/ blog/body-shaming-what-is-it-why-dowe-do-it/.

Wahyuti, Tri. 2018. "Tingkat Kompetensi Anak Muda Dalam Melakukan Literasi Media Digital Melalui Aplikasi Whatsapp." Conference on Dynamic Media, Communications, and Culture 2018 1: 211-23. 